\title{
Metabolic Regulation of Nuclear Receptors
}

\author{
Eun Kyung Lee, Young Joo Park
}

Department of Internal Medicine,

\author{
Seoul National University College of Medicine and Seoul National University Bundang Hospital
}

\section{서 론}

당뇨병, 비만, 이상지질혈증, 고혈압, 인슐린 저항성 등은 공통된 체내 대사 조절의 이상에 의해 발생되는 "대사증후 군(metabolic syndrome)"이라는 병적 상태를 이루는 요소들 이다[1]. 이 대사증후군은 심혈관계 질환으로 인한 사망의 위험성을 높이는데[2], 미국에서는 그 유병률이 $23.7 \%$ 에 이 른다고 알려져 그 심각성이 대두되고 있다[3]. 최근 우리나 라에서 발표된 바에 따르면 대사증후군의 유병률이 $29 \%$ 정 도이며, 주로 사회경제학적 상태가 낮을수록 더 흔한 것으로 알려지면서 이에 대한 그 치료와 예방에 대해 관심이 고조 되고 있다[4]

최근 핵수용체(nuclear receptor; NR)가 대사증후군의 병 태 생리에서 중요한 역할을 담당하고 있음이 밝혀지면서, 핵 수용체의 활성 조절 물질과 그 기전에 대한 연구 및 이를 통 한 대사증후군의 신약 개발에 대한 연구가 활발하게 진행되 고 있다.

핵수용체는 일종의 전사 인자(transcription factor)로 리간 드에 의해 리간드-수용체 반응에 의해 활성화되는 것이 특징 이다. 펩티드 리간드에 의해 반응하는 세포외 수용체와는 달 리, 세포 내로 들어온 지용성 호르몬 혹은 리간드와 직접 결 합하여 핵 안에 위치한 목표 유전자까지 이동하여 전사 기전 을 조절, 해당 유전자의 발현을 조절하는 것이 주된 작용 기 전으로 알려져 있다. 1985년 처음으로 glucocorticoid receptor (GR)가 밝혀진 이래[5], 현재까지 연구 방법의 기술적 발전과 더불어 여러 종류의 핵수용체와 리간드의 존재가 밝혀지고, 이들의 기능과 작용 기전에서 많은 지식이 축적되었다.

본고에서는 지금까지 보고된 연구 결과를 종합하여, 지질 및 당 대사 조절 과정에서 핵수용체가 어떠한 역할을 담당 하고 있으며, 어떤 조절 기전을 통하고 있는가에 대해서 소 개하고자 한다.

\section{핵수용체와 유전자 발현의 조절}

핵수용체는 N-terminal activation function-1 (AF-1), DNA binding domain (DBD), ligand binding domain (LBD), C-terminal AF-2로 이루어지는 공통적인 구조를 가 진다(Fig. 1A). AF-1은 리간드와 독립적으로 활성화되며, $\mathrm{DBD}$ 는 2개의 zinc-finger motif로 이루어져 호르몬 반응 요 소(hormone response element; HRE)라 불리는 특정 DNA sequence에 부착한다. 전형적인 HRE는 대개 6개의 뉴클레 오티드(AGGTCA)로 이루어진 모티프가 몇 개의 뉴클레오 티드를 사이에 두고 2 번 반복되는데 이 뉴클레오티드 개수 (3-4-5 rule)와 모티프가 이어지는 방향(direct-, inverted or everted- repeat)에 따라 핵수용체의 결합 특이도가 결정된다 (Fig. 1B). DBD와 LBD 사이에는 hinge 부위가 존재하는데 이는 하나의 수용체가 여러 개의 HRE sequence에 영향을 줄 수 있도록 한다. C-terminal의 LBD는 수용체의 이합체 형성 (dimerization), 리간드 인식(lignad recognition), cofactor와 의 상호작용(interaction) 등의 기능을 담당한다.

핵수용체는 다음의 두 가지 방법을 통하여 세포 내 목표 유전자의 전사 활성도를 조절, 목표 유전자의 발현을 조절하 는데, GR 등은 리간드가 없는 경우 heat shock protein 등과 결합한 비활성화 상태로 세포질 내에 존재하다가, 리간드가 결합하면 heat shock protein 과 분리되어 핵 내로 이동, 목 표 유전자의 전사를 활성화한다. 한편, TR 등은 리간드가 없는 기저 상태에서 핵 내에 존재하면서 표적 유전자의 hormone response elements (HRE)에 결합, SMRT/NCOR-HDAC와 같은 corepressor와 결합한 상태를 유지하여 기저 상태의 전 사를 억제한다. 리간드가 결합하면 구조적인 변화를 일으켜 corepressor가 분리되고, coactivator가 모여들어 목표 유전 자의 전사 활성화가 일어나게 된다(Fig. 1C). 
A

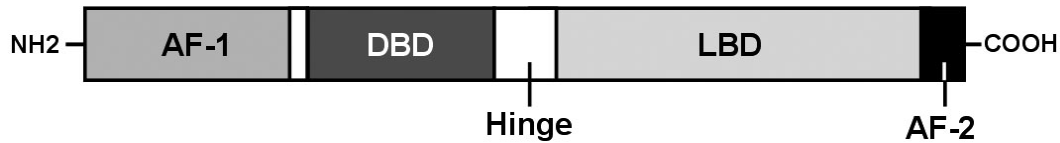

B
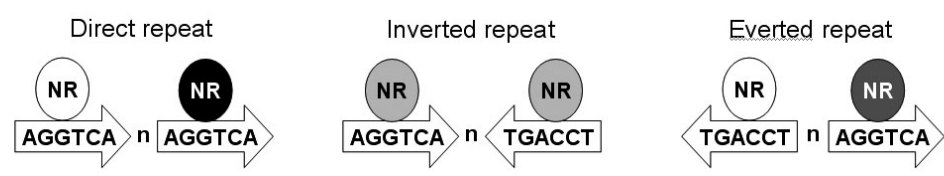

$\mathrm{C}$
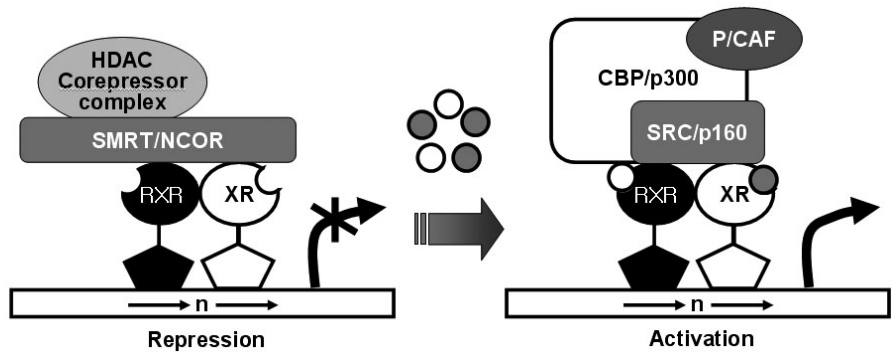

Fig. 1. Nuclear receptors as ligand-dependent transcription factors. A. the structure of the nuclear receptor : N-terminal activation function 1 (AF1), DNA binding, ligand binding, and C-terminal AF2 domains. B. Response elements in the nuclear receptor can be configured as either direct, inverted, or everted repeats of the hexad core sequence AGGTCA. The number of nucleotides between the two core elements (n) confers additional specificity. C. RXR heterodimers constitutively bind to response elements in the promoter regions of target genes.

Table 1. Classification of Nuclear Receptors

\begin{tabular}{|c|c|c|c|c|c|}
\hline \multicolumn{2}{|c|}{ Endocrine receptors } & \multicolumn{2}{|c|}{ Adopted orphan receptors } & \multicolumn{2}{|c|}{ Orphan receptors } \\
\hline NR & Ligand & NR & Ligand & NR & Ligand \\
\hline GR & Glucocorticoid & RXR & 9-cis-retinoic acid & SHP & Unknown \\
\hline MR & Mineralocorticoid & PPAR & Fatty acids & DAX-1 & Unknown \\
\hline PR & Progesterone & LXR & Oxysterol & TLX & Unknown \\
\hline AR & Androgen & FXR & Bile acids & PNR & Unknown \\
\hline ER & Estrogen & PXR & Xenobiotics & GCNF & Unknown \\
\hline TR & Thyroid hormone & CAR & Androstane & TR2,4 & Unknown \\
\hline RAR & Retinoic acid & HNF-4 & Fatty acids & NR4A & Unknown \\
\hline VDR & Vitamin D (bile acid) & ROR & Cholesterol, retinoic acid & Rev-erb & Unknown \\
\hline & & ERR & Estrogen? & COUP-TFII & Unknown \\
\hline
\end{tabular}

NR, nuclear receptor; GR, glucocorticoid receptor; MR, mineralocorticoid receptor; PR, progesteron receptor; AR, androgen receptor; ER, estrogen receptor; TR, thyroid hormone receptor; RAR, retinoic acid receptor; VDR, vitamin D receptor; RXR, retinoid X receptor; PPAR, peroxisome proliferator-activated receptor; LXR, liver X receptor; FXR, farnesoid X receptor; PXR, pregnane X receptor; CAR, constitutive androstane receptor; HNF-4, hepatocyte nuclear receptor-4; ROR, retinoid-related orphan receptor; ERR, estrogen related receptor; SHP, small heterodimer partner; DAX-1, Dosage-sensitive sex reversal-adrenal hypoplasia congenita critical region on the X chromosome, gene 1; TLX, Tailless homolog; PNR, Photoreceptor-specific nuclear receptor; GCNF, Germ cell nuclear factor 1; COUP-TFII, Chicken ovalbumin upstream promoter transcription factor II.

\section{핵수용체의 종류}

핵수용체는 리간드와 기능에 따라 크게 세 가지로 분류할 수있다(Table 1)[6]. 첫 번째 종류는 지용성 호르몬과 비타 민에 대한 endocrine receptor로 리간드에 대한 친화도가 매 우 높은 것이 특징이다. 갑상선 호르몬(thyroid hormone receptor, TR), 당질코르티코이드(glucocorticoid receptor, GR), vitamin A (retinoic acid receptors; RAR), vitamin D (vitamin D receptor; VDR)의 수용체가 여기에 속한다. GR 등은 homodimer를 이루어 작용하며, TR, VDR, RAR 등은 retinoid X receptor (RXR)과 함께 heterodimer를 이룬다.

두 번째 종류는 수용체를 발견할 당시에는 기능과 리간드 를 알지 못하여 orphan receptor로 분류되었으나 추후 리간 드를 발견하게 된 adopted orphan receptor이다. 이들은 지 질이나 약물에 대해 친화도가 비교적 낮으며 RXR과 heterodimer를 이룬다[7]. 특히 이 종류의 핵수용체들이 지 
질과 당 대사 조절 기전에 미치는 역할에 대한 활발한 연구 가 진행되고 있으며, 이를 통하여 대사 질환의 치료 약제의 개발가능성이 제시되고 있다. 실제로 PPAR $y$ 나 $a$ 를 통해 작 용하는 thiazolidinedione, fibrate 등의 약물은 고혈당과 인 슐린 저항성 개선, 고지혈증 치료 등에 효과가 있어 이미 시 판되어 임상에서 사용 중이다.

아직까지도 리간드가 알려져 있지 않은 수용체는 orphan receptor로 불리운다. 이들은 약제를 통한 변화를 관찰하기 어렵기 때문에 연구를 하는 데 있어 제한점이 있으나, 최근 이들이 대사조절에 미치는 역할에 대한 연구도 활발히 진행 되고 있다.

\section{핵수용체가 대사조절에 미치는 영향과 기전}

대부분의 endocrine receptor들이 대사 항상성을 유지하 는 데 있어 중요한 역할을 담당한다. 특히, 성 호르몬이나 갑상선 호르몬, 당질코르티코이드(glucocorticoids) 등이 과 다하거나 부족하게 되면 여러 복잡한 증상과 징후를 동반하 는 질환이 발생함이 잘 알려져 있다. 이들 호르몬의 주된 영 향은 말초장기에서 각자의 수용체와 결합하여 나타나는데, 이들은 체내 대사 조절에 있어서도 상호 긴밀한 영향을 주
면서 복잡한 대사 과정의 조절에서 중요한 역할을 수행하고 있다. 본고에서는 여러 호르몬과 핵수용체 중, 지질 및 당대 사 조절과의 밀접한 연관이 보고되고 있는 대표적인 수용체 와 지금까지 밝혀진 기전에 대해 간략히 소개하고자 한다 (Table 2).

\section{1. 당질코르티코이드 수용체 (Glucocorticoid Receptor, GR)}

당질코르티코이드는 부신에서 합성되는 스테로이드 호르 몬으로, 공복 시나 여러 스트레스 상황에서 주로 생산되어 $\mathrm{GR}$ 을 통해 작용한다. 공복 시 간 내에서는 포도당 신합성 (hepatic gluconeogenesis)과 글리코겐 합성을 촉진하고, 말 초 조직에서는 아미노산의 분해와 지방 조직 생성, 인슐린 저항성을 촉진한다. 당질코르티코이드가 과잉 생성되는 질 환인 쿠싱 증후군에서 복부 비만과 고혈당이 발생하는 기 전이 여기에 있다. 쥐 모델에서 지방조직 특이적으로 당질 코르티코이드를 증가시키면 복부 지방이 증가하고 식욕 촉 진, 고지혈증, 고혈압, 그리고 인슐린 저항성이 발생하는 반 면, 당질코르티코이드의 발현을 감소시키면 에너지 소비가 증가하면서 식이에 의한 비만이나 당뇨병이 발생하는 것을

Table 2. Nuclear Receptors Associated with Metabolic Disease, and Their Synthetic Ligands

\begin{tabular}{|c|c|c|c|}
\hline $\begin{array}{l}\text { Nuclear } \\
\text { Receptor }\end{array}$ & Ligands (physiologic/synthetic) & $\begin{array}{l}\text { Known physiologic } \\
\text { functions }\end{array}$ & $\begin{array}{l}\text { Known associated metabolic disease } \\
\text { or pathogenesis }\end{array}$ \\
\hline \multirow[t]{2}{*}{ GR } & \multirow{2}{*}{$\begin{array}{l}\text { Glucocorticoid/dexamethasone, RU38486, } \\
\text { A348441 }\end{array}$} & Lipolysis & Visceral obesity \\
\hline & & Glucose metabolism & Hyperglycemia \\
\hline \multirow[t]{3}{*}{$\operatorname{TR} a, \beta$} & \multirow[t]{3}{*}{ Thyroid hormone / GC-1, KB-141 } & Metabolic rate & Cardiac dysfunction \\
\hline & & Neural development & Dyslipidemia \\
\hline & & Cholesterol metabolism & Obesity \\
\hline PPAR $a$ & $\begin{array}{l}\text { Fatty acids / Fibrate (Gemfibrozil, fenofibrate, } \\
\text { clofibrate), WY14643 }\end{array}$ & Fatty acid oxidation & $\begin{array}{l}\text { Dyslipidemia, Atherosclerosis } \\
\text { Diabetic cardiomyopathy }\end{array}$ \\
\hline \multirow[t]{3}{*}{$\operatorname{PPAR} y$} & \multirow{3}{*}{$\begin{array}{l}\text { Fatty acids, eicosanoids / thiazolidinedione } \\
\text { (pioglitazone, rosiglitazone), } \\
\text { FMOC-L-Leucine }\end{array}$} & Adipogenesis & Insulin resistance \\
\hline & & Lipid storage & Obesity \\
\hline & & & Metabolic syndrome \\
\hline \multirow[t]{2}{*}{$\operatorname{PPAR} \delta$} & \multirow{2}{*}{ Fatty acids / GW501516, KD3010 } & Fatty acid oxidation & Dyslipidemia, Obesity \\
\hline & & Energy expenditure & Atherosclerosis \\
\hline \multirow[t]{2}{*}{$\operatorname{LXR} a, \beta$} & \multirow[t]{2}{*}{ Oxysterol / T0901317, GW3965 } & Cholesterol homeostasis & Dyslipidemia \\
\hline & & Fatty acid synthesis & Atherosclerosis \\
\hline \multirow[t]{3}{*}{ FXR } & \multirow{3}{*}{$\begin{array}{l}\text { Bile acid / guggulsterone (antagonist), } \\
\text { Chenodeoxycholic acid (agonist), } \\
\text { Fexaramine, GW4046 }\end{array}$} & \multirow[t]{3}{*}{ Bile acid homeostasis } & Hypercholesterolemia \\
\hline & & & Biliary cholestasis, \\
\hline & & & Dyslipidemia \\
\hline CAR & Androstenol / CITCO, ТСРОВOP & Chemical metabolism & Biliary cholestasis, jaundice \\
\hline PXR & Pregnolone, glucocorticoid / SR12813 & Chemical metabolism & Biliary cholestasis, jaundice \\
\hline SHP & unknown & Bile acid homeostasis & Mild obesity \\
\hline
\end{tabular}

GR, glucocorticoid receptor; TR, thyroid hormone receptor; PPAR, peroxisome proliferator-activated receptor; LXR, liver X receptor; FXR, farnesoid X receptor; PXR, pregnane X receptor; CAR, constitutive androstane receptor; SHP, small heterodimer partner. 
방지한다. 간에서 $\mathrm{GR}$ 을 비활성화하면 공복 시 저혈당이 발 생하게 되고 당뇨병 쥐 모델에서도 혈당을 낮추는 효과가 나타난다. 이처럼 당질코르티코이드를 억제하면 당 대사와 에너지 대사를 조절할 수 있지만 현재까지 부작용이 많아 서 대사증후군의 치료 방법으로 이용되지 못하고 있다. 다 만 11b-hydroxysteroid dehydrogenase type I에 대한 선택적 억제제를 투여하면 대사증후군이나 동맥경화증에 도움이 된 다는 보고가 있다[8].

\section{2. 갑상선 호르몬 수용체}

\section{(Thyroid Hormone Receptors, TR)}

갑상선 호르몬 수용체(thyroid hormone receptors, TR)은 전신에 발현되어 지질과 당의 대사는 물론 혈압과 체구성 성분을 변화시킨다. 특히 reverse cholesterol transport의 결 정적인 역할을 하는 효소인 cholesteryl ester transfer protein이 갑상선 호르몬 농도에 따라 민감하게 변하기 때문 에 갑상선 기능에 따라 지질 대사가 변하는 것으로 알려져 있다[9]. 또한 갑상선 호르몬 수용체(TR)를 활성화시키면 대 사가 증가하고 체중이 감소하기 때문에 대사증후군의 치료 제로서의 가능성이 적극적으로 연구되었으나, 실제로 TR 작 용제를 투여하면 심장과 뼈 등에 원하지 않는 부작용이 유 발되어, 이러한 부작용을 최소화하기 위하여 DITPA, GC-1, $\mathrm{KB}-141, \mathrm{~KB}-2155$, Triac 등 TR에 대한 선택적 작용제에 대한 연구가 활발히 진행되고 있다 $[10,11]$.

갑상선호르몬 혹은 갑상선호르몬 유도체를 투여하면 혈 중 $\mathrm{LDL}$ cholesterol, 중성 지방, 죽상경화를 촉진하는 지단 백(proatherogenic lipoprotein) 등의 감소가 나타나는데, 이 는 기초 대사율을 증가시킴으로써 체내 전반적인 에너지 소
모를 증가시키는 기전 이외에도 지질 대사에 영향을 주기 때문이다. $\mathrm{LDL}$ 수용체를 증가시켜 $\mathrm{LDL}$ 농도를 낮추고, apolipoprotein (a)을 감소시키며, HDL를 증가시킬 뿐 아니 라 CYP7A를 통해 담즙 생성을 증가시켜 지질 대사를 원활 히 한다[11,12]. 그러나 당대사에서는 기초 대사율을 증가시 키기는 하나 포도당 신합성과 말초 인슐린저항성을 증가시 키며 인슐린의 제거율을 높여 보상적으로 인슐린 분비를 촉 진하는 등 좋지 않은 영향을 준다(Fig. 2). 그러나 실제로 쥐 에 $\mathrm{T}_{3}$ 를 투여하면 공복혈당이 증가하나 $\mathrm{TR} \beta$ 작용제를 투여 하였을 때에는 증가하지 않았다[13].

\section{Peroxisome Proliferator-Activated Receptors (PPAR)}

Peroxisome proliferator-activated receptors (PPAR)는 그 이름에서 알 수 있듯 peroxisome proliferator에 의해 활성화 되는 핵수용체로, RXR과 heterodimer를 이루어 작용한다. $a, \beta / \delta, y$ 의 3 가지 종류가 있으며, 그 중 PPAR $a$ 는 peroxisome proliferator와 지질강하제의 하나인 fibrate가 리간드로 결합 하는 것으로 알려져 있다. PPARa는 주로 간, 심장, 근육, 신 장에 발현하여 지방산의 산화와 아포지단백의 합성을 조절 한다. 특히 공복 시 간 내에서 지방산을 산화하기 때문에, $\operatorname{PPAR} a$ 결핍 쥐는 장시간 금식하거나 혹은 고지방 식이를 섭취하면 간에 지방이 축적된다. 또한 PPAR $a$ 는 혈관 벽이 나 대식세포에도 존재하여 항염증 혹은 항동맥경화 작용을 한다(Fig. 3). 임상연구에 따르면 PPAR $a$ 작용제는 고지질혈 증을 개선할 뿐만 아니라 심혈관계 질환으로 인한 사망률을 줄일 수 있다[14].

$\operatorname{PPAR} y$ 는 주로 지방 조직에 발현하여 아디포넥틴과 같은 인슐린 감수성 아디포카인의 생성에 관여함으로써 지방 세

Thyroid hormone

Synthetic agonist (DITPA, L940901, KB-141)

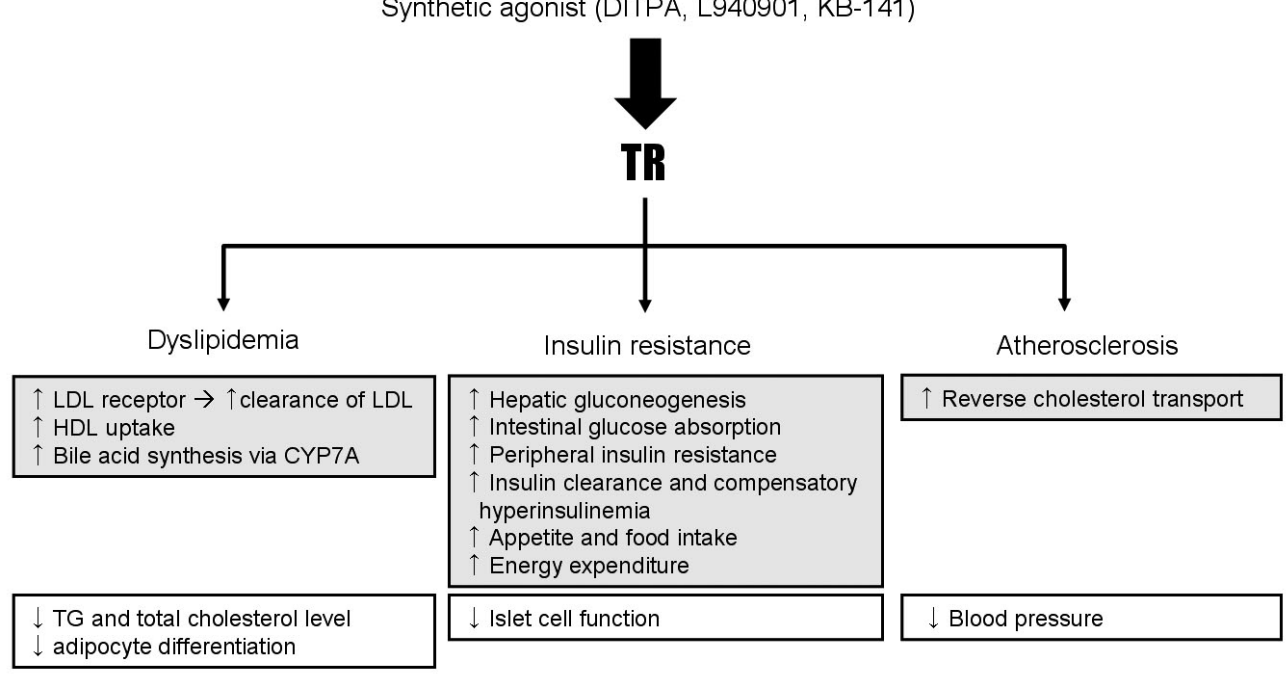

Fig. 2. Metabolic regulation by thyroid hormone receptor (TR). 
포 내에 지방이 축적되는 것을 조절하고 당 대사에 관여한 다. PPARy 리간드로는 지방산이나 eicosanoid 등의 내인성 물질과, 인슐린 감수성을 높이는 thiazolidinedione (TZD) 계열 약제가 알려져 있다. PPAR $y$ 를 조직 특이적으로 제거 한 한 연구에 따르면 간과 근육의 PPAR $r$ 는 실제로 발현되 는 정도는 매우 낮음에도 TZD의 효과 대부분에 기여한다. 그런데, 사람의 $\operatorname{PPAR} y$ 유전자 다형성은 이와는 상이한 임 상상을 보여주는데, PPAR $y$ 의 loss-of-function mutation 인 Pro12Ala 유전자형을 가진 사람에서는 인슐린 감수성이 증 가하고 저체중인 반면, gain-of-function mutation인 Pro115Gln 유전자형의 사람에서는 비만과 인슐린 저항성이 증가한대[15]. 이는 PPAR $y$ 의 활성화가 인슐린 감수성을 호전시키는 동시 에 지방 세포의 분화를 촉진시켜 반대로 인슐린 저항성을 증가시킴을 시사하는 것이다. 그러므로 이러한 결과에서 $\operatorname{PPAR} y$ 의 부분 작용제(partial agonist)가 완전 작용제(full agonist)보다 인슐린 감수성을 높이는 데에 효과적임을 시사 한다[16]. TZD는 현재 rosiglitazone과 pioglitazone이 개발되 어 사용 중인데, 체중 증가, 간 독성, 심장에 대한 부작용 등 이 보고되어 새로운 2세대 PPARy 작용제가 개발 중이다.

$\operatorname{PPAR} \delta$ 는 전신에 발현하여 지방산이나 VLDL에 의해 활 성화된다[17]. PPAR $\delta$ 에 의해 발현 조절되는 단백은 주로 갈색 지방 내의 베타 산화를 조절하거나(Long chain/very long chain acyl-CoA synthetase, long chain/very long chain acyl-CoA dehydrogenase, acyl-CoA oxidase), 에너지 대사(uncoupling proteins 1,3 ), 지방 저장(macrophage adipose differentiation-related protein)에 관여한다. $\operatorname{PPAR} \delta$ 결핍 쥐 는 대부분 임신 중반에 치사하고, 살아남은 쥐의 경우에는 지방 조직이 뚜렷하게 감소되어 있다. PPAR $\delta$ 를 발현을 증 가시키면 지방산의 베타 산화와 에너지 소모가 많아지고 따
라서 식이에 의한 비만이 감소한다. 또한 PPAR $\delta$ 는 VLDL 에 의해 대식 세포에 지질이 축적되는 과정에도 관여한다. $\operatorname{PPAR} \delta$ 작용제는 혈중 $\mathrm{HDL}$ 의 증가, $\mathrm{LDL}$, 중성지방, 공복 시 혈당의 감소를 유도한다. 그러므로 PPAR $\delta$ 만을 활성화하 는 약제를 치료에 이용하면 PPAR $y$ 를 거치지 않은 지방 조 직 생성 과정을 억제할 수있을 것으로 기대되고 있다[18] (Fig. 3).

\section{Liver X Receptor (LXR)}

Liver X receptor (LXR)는 산화된 콜레스테롤 부산물 (oxysterol, 산화스테롤)에 결합하는 핵수용체로, $\operatorname{LXR} a$ 는 주 로 간, 지방 조직, 장, 대식 세포, 신장에 발현되고, $\operatorname{LXR} \beta$ 는 모든 장기에 발현된다. 세포 내에 산화스테롤(oxysterol)이 증가하면 LXR은 말초 조직에서 간으로 콜레스테롤을 운반 하는 단백의 유전자들을 활성화시킨다. 대식세포에서는 콜 레스테롤 방출을 유도하는 단백(ABCA1, ABCG1)을 유도 하고, 혈중 콜레스테롤의 운반과 간으로 유입을 조절하는 단 백(apolipoprotein E, phospholipid transfer protein, lipoprotein lipase, cholesterol ester transfer protein), 콜레스테롤을 분 해하여 담즙으로 배설하는 과정에 관여하는 단백(CYP7A1, ABCG5, ABCG8), 장내 콜레스테롤의 흡수를 억제하는 단 백(ABCG5, ABCG8, ABCA1)의 발현을 유도한다. 또한 지 방산과 중성지방을 많이 합성하기 위해 지방산 대사에서 가 장 중요한 효소인 sterol regulatory element-binding protein1c (SREBP-1c)의 발현을 증가시킨다[19](Fig. 4).

LXR은 콜레스테롤 대사를 조절할 뿐만 아니라, 동맥경화 와 고콜레스테롤혈증 등의 병적인 상태에서 방어적인 역할 을 한다는 것이 동물 실험을 통해 알려졌다. LXR $a$-knockout mice는 섭취한 콜레스테롤을 흡수, 제거하는 데 문제가 있

Fatty acid, Eicosanoids

Synthetic agonist (bezafibrate, thiazolidinediones, GW501516, L165041)

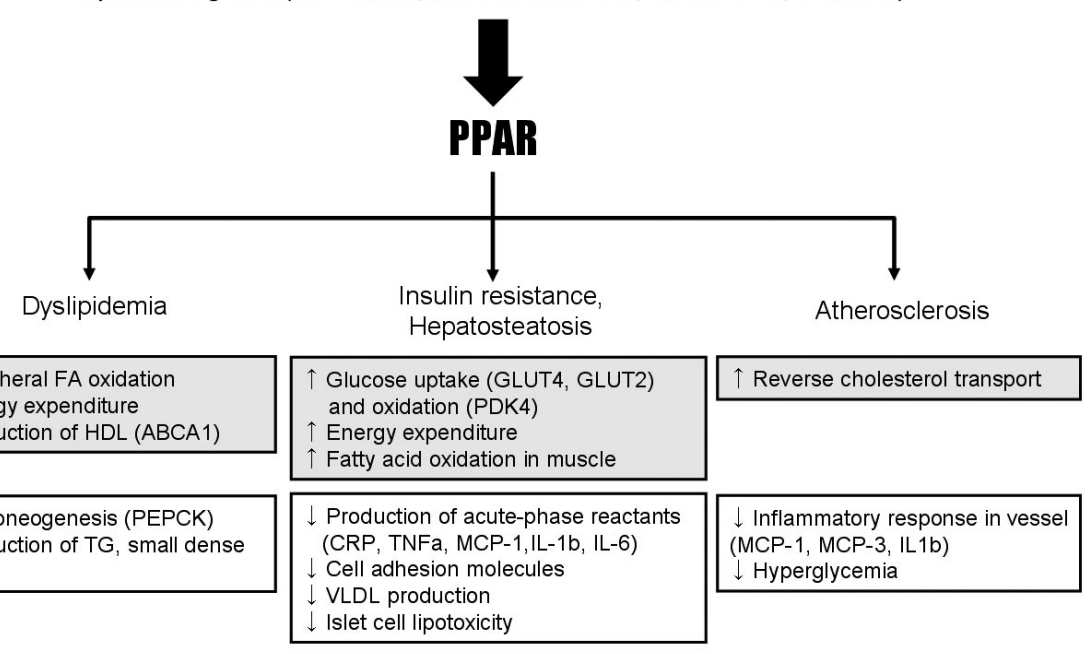

Fig. 3. Metabolic regulation by peroxisome proliferator-activated receptor (PPAR). 


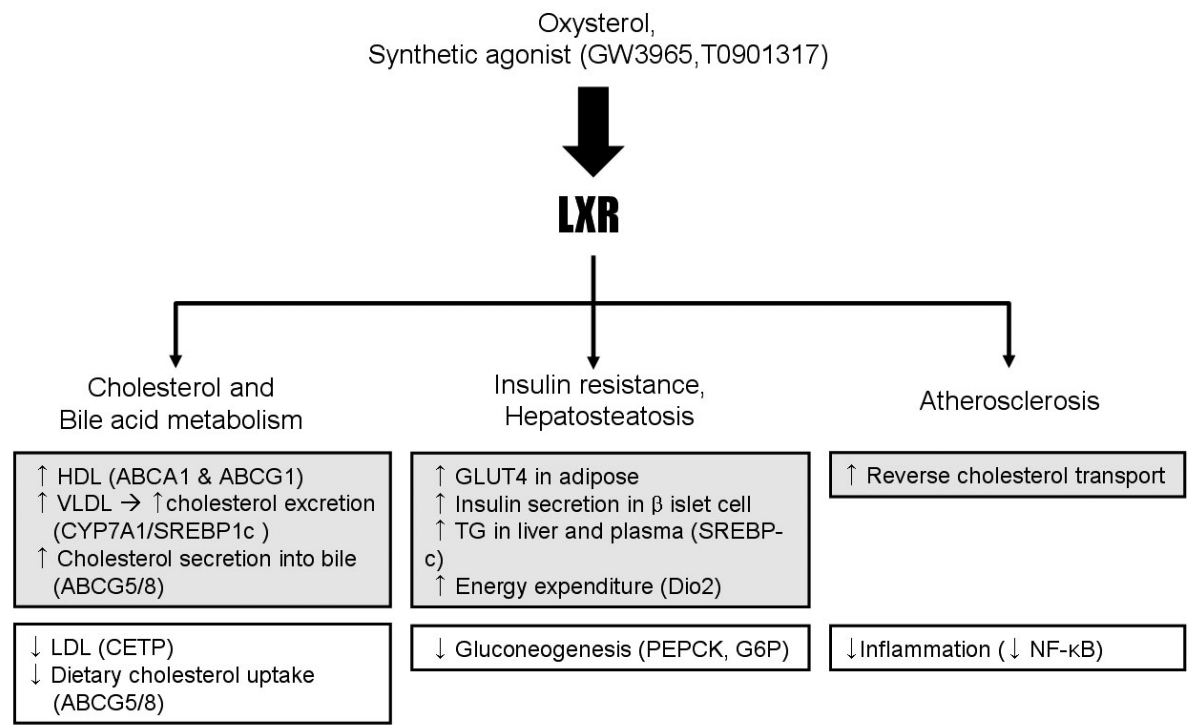

Fig. 4. Metabolic regulation by Liver $\mathrm{X}$ receptor (LXR).

어 cholesterol ester가 간에 축적되어 결국 간부전에 이른다. LXR 작용제를 투여하면 SREBP-1c의 발현이 증가하면서 간과 혈청 중성지방이 높아지는 문제가 있으나 이는 주로 간 내 LXR 0 에 의해 매개되는 것으로 알려져, LXR 에 보다 선택적인 작용제를 개발하여 콜레스테롤의 축적은 억제하면 서 동맥경화 역시 감소시키려는 연구가 진행되고 있대[20,21]. 최근 한 연구에서는 혈청 포도당이 $\mathrm{LXR} a$ 과 $\mathrm{LXR} \beta$ 에 직접 적인 작용제로 작용하여 산화스테롤과 동일한 유전자들을 발현 유도하고, 공복 상태의 쥐에 당분을 공급하면 LXR에 의해 발현되는 콜레스테롤 대사 관련 효소들도 역시 발현이 증가됨이 보고되었다. 이는 $\mathrm{LXR}$ 이 간 내 당 대사와 지방산 합성 과정에 스위치 역할을 할 가능성을 시사하는 것이다[19].

\section{Farnesoid X Receptor (FXR)}

FXR (farnesoid X receptor)는 담즙산 \{chenodeoxycholic acid (CDCA), cholic acid (CA)\}에 대한 핵수용체로 담즙 의 장간순환계, 신장, 부신에 발현된다[22,23]. FXR에 의해 발현 유도되는 유전자들은 주로 담즙산을 분비하거나 phospholipid를 담즙으로 배출하는 단백(bile salt efflux pump, multidrug-resistance protein 2,3), 혈액 내 HDL에 서 콜레스테롤을 간으로 운반하는 단백(phospholipid transfer protein)의 발현에 관여한다. 간접적으로는 담즙산 생성의 속도결정단계 효소인 CYP7A1를 negative feedback 을 통해 억제한다. FXR 결핍 쥐는 혈중 담즙산 농도가 증가 하고 전체 담즙산의 양이 증가하며 대변으로의 담즙산 배출 이 증가한다[24]. 이는 간에서 담즙산이 생성되는 기전을 억 제하는 피드백 기전이 손상되면서 담즙산의 생성과 배설의 균형이 무너진 결과라 할 수 있다. 이러한 불균형은 혈청 총 콜레스테롤과 중성지방을 증가시키면서 $\mathrm{HDL}$ 의 분해를 억
제하여 $\mathrm{HDL}$ 농도 역시 상승시킨다. 따라서 FXR 작용제 를 투여하면 간과 혈청 중성지방을 감소시킬 수 있대[25] (Fig. 5).

\section{Pregnane X Receptor (PXR)과 Constitutive Androstane Receptor (CAR)}

Pregnane X receptor (PXR)과 Constitutive androstane receptor (CAR)는 간과 장에 발현되어 약물 대사에 관여한 다. PXR은 리간드 부착 부위가 유연성을 가지고 있어 수많 은 약물과 결합할 수 있다. 한편 CAR는 핵 내에 위치한 것 많이 활성도를 가지고 있으며, 세포막에 결합된 인산화효소 의 신호전달체계를 통해 약물이 활성화되어 핵 내로 유입되 어 작용한다. 이처럼 작용 기전이 다름에도 불구하고 PXR 과 $\mathrm{CAR}$ 는 약물 대사에 관여하는 수많은 유전자들을 동시에 함께 조절하고 있다.

PXR과 CAR는 체외에서 흡수된 약물뿐 아니라 스테로이 드 호르몬이나 체내에 축적된 빌리루빈이나 콜레스테롤 대 사물의 제거에도 관여한다. 한 예로 PXR 작용제인 리팜핀 은 담즙 정체로 인한 소양감을 호전시킬 수 있다[26]. 뿐만 아니라 포도당 신합성(gluconeogenesis)와 글리코겐 분해 (glycogenolysis)에서 중요한 glucose-6-phosphatase (G6Pase)와 phosphoenolpyruvate carboxykinase 1 (PEPCK1)의 전사 조절에도 $\mathrm{CAR} / \mathrm{PXR}$ 이 연관되어 있다[27] (Fig. 6).

당뇨병 환자에게 phenobarbital을 장기간 투여할 경우 혈당이 감소하고 인슐린 감수성이 호전된다는 것은 일찍이 보고된 바 있다[28]. 최근 $\mathrm{CAR}$ 작용제인 1, 4-bis[2-(3,5dichloropyridyloxy)] benzene (ТCРOBOP)를 투여한 쥐에 서 간 내 PEPCK1과 G6Pase의 발현이 억제되고, PXR 작용 제인 pregnenolone 16a-carbonitrile $(\mathrm{PCN})$ 를 투여한 쥐에서 


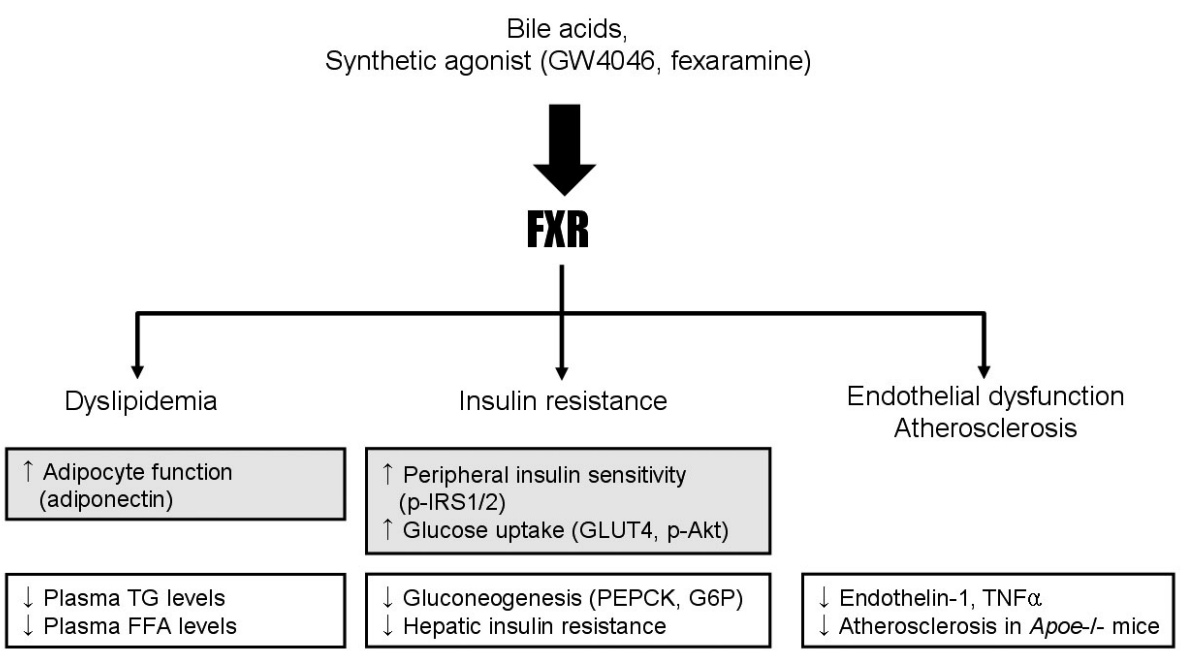

Fig. 5. Metabolic regulation by farnesoid $X$ receptor (FXR).

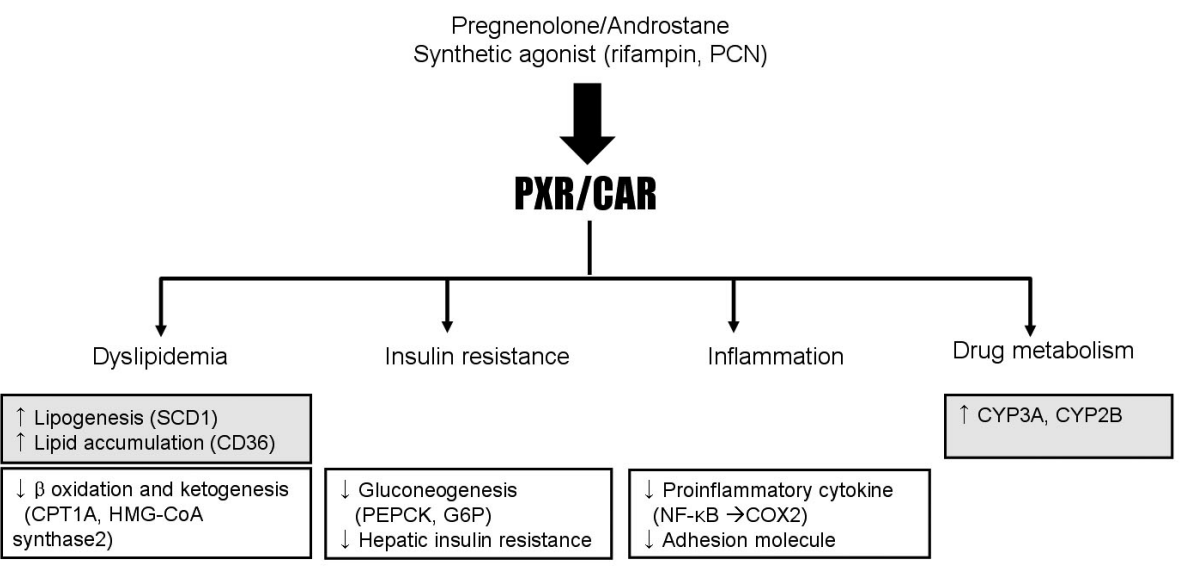

Fig. 6. Metabolic regulation by pregnane $X$ receptor (PXR) and constitutive androstane receptor (CAR).

도 혈당이 감소하지만 Pxr-/- mouse에서는 그렇지 않았대[27]. 또한 Car-/-, Pxr-/- mouse 모델을 통해 이들 핵수용체가 간 내 당 대사에서 일차 조절 인자로 작용함을 확인되었다[29]. $\mathrm{CAR}$ 와 PXR은 forkhead transtription factor 1 (FoxO1), c-AMP-response element binding protein (CREB), peroxisome proliferator-activated receptor $y$ coactivator 1 (PGC1) $a$ 에 의한 G6Pase와 PEPCK1 활성화를 억제함으로 써 이러한 영향을 미치는 것으로 보고되고 있다[30].

한편, 간에서 일어나는 지질 대사는 장기간의 금식 혹은 운동 시 필요한 에너지를 공급하기 위해 필수적인 과정이다. 혈당이 내려가면 간은 지방산을 산화하고 케톤산을 만들어 내어 각 조직에 케톤체의 형태로 에너지를 공급한다. 이 베 타 산화와 케톤산 생성의 과정에 중요한 효소인 carnitine palmitoyltransferase 1A (CPT1A)와 mitochondrial 3-hydroxy -3-methylglutarate-CoA synthase 2 (HMGCS2)는 발현 유 도되고, 반대로 식사 후에는 stearoyl-CoA desaturase 1 (SCD1)가 증가하여 불포화 지방산을 합성해낸다. 최근 연구
에 의하면 PXR 작용제인 PCN은 CPT1A와 HMGCS2를 억 제하는데 반해 Pxr-/- mice에서는 그러한 변화가 소실되었 다. 이는 PXR에 의해 CPT1A와 HMGCS2 유전자가 발현 조절됨을 의미하며 PXR에 의해 lipid metabolism이 변화한 다는 사실을 시사하는 결과이다.

\section{Small Heterodimer Partner (SHP)}

Small heterodimer partner (SHP)는 DBD를 갖고 있지 않아 주로 다른 핵수용체를 억제하는 작용을 한다. SHP은 대부분 간에서 발현되어 FXR이 주관하는 콜레스테롤의 분 해 과정에 관여한다[25] (Fig. 7). 콜레스테롤을 담즙을 통해 배설하는 과정에서 속도 결정단계 효소는 CYP7A1으로, 담 즙이 FXR에 결합하면 SHP이 유도되어 CPY7A1이 억제되 는 음성 되먹임기전(negative feedback)이 일어나고, LRH-1 을 통해 CYP7A1이 조절(positive regulation)된다. SHP-/mice는 담즙 생성 조절에 문제가 발생하여 과도하게 담즙이 생산되면서 비정상적인 간 내 담즙 정체가 일어나고, FXR 


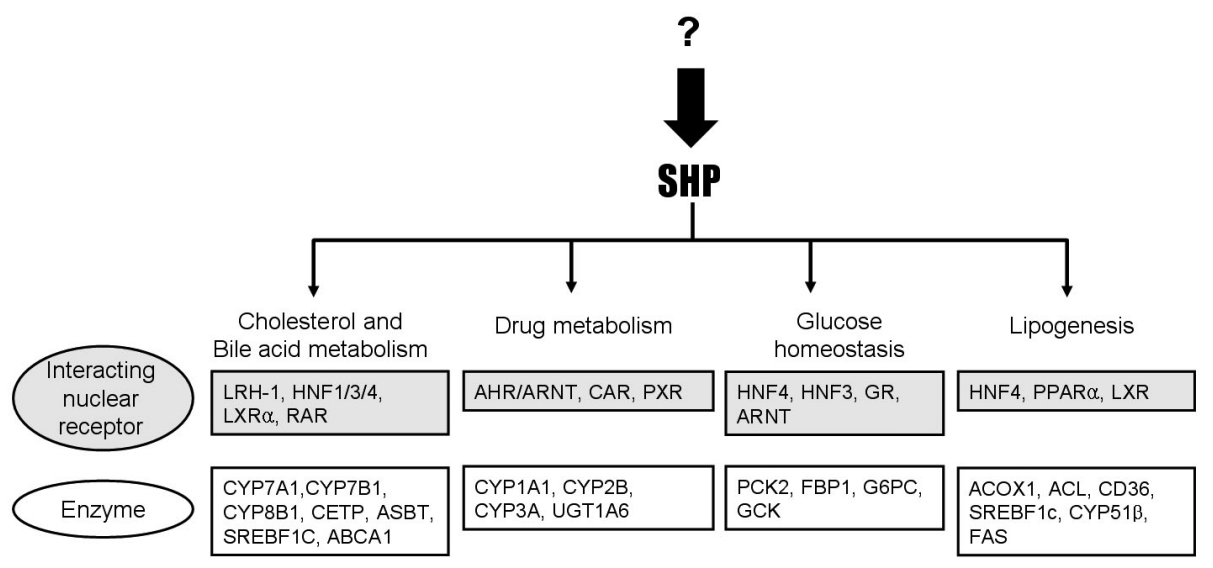

Fig. 7. Metabolic regulation by small heterodimer partner (SHP)

특이적 작용제를 투여해도 CYP7A1의 억제가 일어나지 않 는다.

FXR을 통해 SHP의 발현이 증가할 때 SREBP-1c의 발현 이 억제되면서 중성지방과 간 내 콜레스테롤, 산화스테롤이 저하된다. LXR이 활성화되면 SREBP- $1 \mathrm{c}$ 도 활성화되어 VLDL과 중성지방을 증가시키는데, SHP은 LXR가 SREBP-1c 의 promoter 부위에 결합하는 과정을 저해하는 것으로 생 각되고, 여기에는 $\mathrm{PGC}-1$ 이 관여할 것으로 최근 보고되었 다[31].

$\mathrm{SHP}$ 은 당 대사에도 관여하여, SHP에 의해 G6Pae와 $\mathrm{PEPCK}$ 의 promoter가 억제되는 것이 보고되었다. 콜레스테 롤의 대사 과정이 FXR에 의해 SHP의 발현이 조절됨으로써 변하는 것처럼, 당 대사 과정에서는 HNF-4a를 통해 PEPCK 와 fluctose bisphosphate (FBP)를 발현 조절하거나, Foxo1 을 통해 G6Pase를 조절한다[32]. 또한, SHP은 췌장의 베타 세포의 인슐린 분비를 조절하는 것으로도 보고되고 있다[33]. 즉 SHP은 간의 포도당 생성 및 베타 세포의 인슐린 분비 조 절 유전자의 발현 조절에 중요한 역할을 담당하며, 이러한 결과에서 당 대사 과정에 FXR-SHP cascade라는 새로운 기 전이 존재할 가능성이 제시되고 있다 $[34,35]$.

이처럼 SHP은 당과 지질 대사에 중요한 역할을 하지만 현재까지 구조는 물론 리간드도 알려져 있지 않아 SHP 특 이적 작용제/저해제를 개발함에 있어 어려움이 있다. 최근 시도되고 있는 노력은 SHP 리간드를 찾거나 SHP의 발현을 조절하는 전사인자에 초점이 맞추어지고 있다.

\section{결 론}

핵수용체는 지용성 리간드에 의해 그 전사 여부가 조절되 는데, 반대로 핵수용체 자체도 지질이나 당 대사에 영향을 준다. 따라서 핵수용체의 구조와 기능을 분석함으로써 대사 증후군의 치료제 개발에 훌륭한 후보물질을 개발할 수 있을
것으로 생각된다. 현재까지 핵수용체에 대한 합성 리간드는 Table 2에서 열거된 바와 같이 매우 다양한 범위에 걸쳐 개 발되고 있다. 또한 핵수용체들의 cofactor 들도 지방의 합성 과 산화, 당 대사 등 넓은 범위에 걸친 대사 과정에 영향을 주고 있어 역시 후보 신약 개발이 진행 중이다. 핵수용체를 경유한 신호 전달 체계에 대해 보다 심층적으로 이해함으로 써 급증하고 있는 대사증후군을 이해하고 치료할 수 있는 발판이 될 수 있을 것으로 기대된다.

\section{참 고 문 헌}

1. Grundy SM, Brewer HB, Jr., Cleeman JI, Smith SC, Jr., Lenfant C: Definition of metabolic syndrome: Report of the National Heart, Lung, and Blood Institute/American Heart Association conference on scientific issues related to definition. Circulation 109: 433-438, 2004

2. Lakka HM, Laaksonen DE, Lakka TA, Niskanen LK, Kumpusalo E, Tuomilehto J, Salonen JT: The metabolic syndrome and total and cardiovascular disease mortality in middle-aged men. JAMA 288: 2709-2716, 2002

3. Ford ES, Giles WH, Dietz WH: Prevalence of the metabolic syndrome among US adults: findings from the third National Health and Nutrition Examination Survey. JAMA 287:356-359, 2002

4. Park MJ, Yun KE, Lee GE, Cho HJ, Park HS: A cross-sectional study of socioeconomic status and the metabolic syndrome in Korean adults. Ann Epidemiol 17:320-326, 2007

5. Hollenberg SM, Weinberger C, Ong ES, Cerelli G, Oro A, Lebo R, Thompson EB, Rosenfeld MG, Evans 
RM: Primary structure and expression of a functional human glucocorticoid receptor cDNA. Nature 318: 635-641, 1985

6. Sonoda J, Pei L, Evans RM: Nuclear receptors: decoding metabolic disease. FEBS Lett 582:2-9, 2008

7. Glass CK: Differential recognition of target genes by nuclear receptor monomers, dimers, and heterodimers. Endocr Rev 15:391-407, 1994

8. Walker BR, Andrew R: Tissue production of cortisol by 11beta-hydroxysteroid dehydrogenase type 1 and metabolic disease. Ann N Y Acad Sci 1083:165-184, 2006

9. Duntas LH, Wartofsky L: Cardiovascular risk and subclinical hypothyroidism: focus on lipids and new emerging risk factors. What is the evidence? Thyroid 17:1075-1084, 2007

10. Grover GJ, Mellstrom K, Ye L, Malm J, Li YL, Bladh LG, Sleph PG, Smith MA, George R, Vennstrom B, Mookhtiar K, Horvath R, Speelman J, Egan D, Baxter JD: Selective thyroid hormone receptor-beta activation: a strategy for reduction of weight, cholesterol, and lipoprotein (a) with reduced cardiovascular liability. Proc Natl Acad Sci USA 100:10067-10072, 2003

11. Moreno M, de Lange P, Lombardi A, Silvestri E, Lanni A, Goglia F: Metabolic effects of thyroid hormone derivatives. Thyroid 18:239-253, 2008

12. Cappola AR, Ladenson PW: Hypothyroidism and atherosclerosis. J Clin Endocrinol Metab 88:2438-2444, 2003

13. Erion MD, Cable EE, Ito BR, Jiang H, Fujitaki JM, Finn PD, Zhang BH, Hou J, Boyer SH, van Poelje PD, Linemeyer DL: Targeting thyroid hormone receptor-beta agonists to the liver reduces cholesterol and triglycerides and improves the therapeutic index. Proc Natl Acad Sci USA 104:15490-15495, 2007

14. Shulman AI, Mangelsdorf DJ: Retinoid X receptor heterodimers in the metabolic syndrome. $\mathrm{N}$ Engl $\mathrm{J}$ Med 353:604-615, 2005

15. Bosse Y, Despres JP, Bouchard C, Perusse L, Vohl MC: The peroxisome proliferator-activated receptor alpha L162V mutation is associated with reduced adiposity. Obes Res 11:809-816, 2003

16. Muise ES, Azzolina B, Kuo DW, El-Sherbeini M, Tan Y, Yuan X, Mu J, Thompson JR, Berger JP, Wong $\mathrm{KK}$ : Adipose fibroblast growth factor 21 is up-regulated by PPARy and altered metabolic states. Mol
Pharmacol, 2008 [Epub ahead of print]

17. Chawla A, Lee $\mathrm{CH}$, Barak Y, He W, Rosenfeld J, Liao D, Han J, Kang H, Evans RM: PPARdelta is a very low-density lipoprotein sensor in macrophages. Proc Natl Acad Sci USA 100:1268-1273, 2003

18. Oliver WR, Jr., Shenk JL, Snaith MR, Russell CS, Plunket KD, Bodkin NL, Lewis MC, Winegar DA, Sznaidman ML, Lambert MH, Xu HE, Sternbach DD, Kliewer SA, Hansen BC, Willson TM: A selective peroxisome proliferator-activated receptor delta agonist promotes reverse cholesterol transport. Proc Natl Acad Sci USA 98:5306-5311, 2001

19. Mitro N, Mak PA, Vargas L, Godio C, Hampton E, Molteni V, Kreusch A, Saez E: The nuclear receptor LXR is a glucose sensor. Nature 445:219-223, 2007

20. Torra IP, Ismaili N, Feig JE, Xu CF, Cavasotto C, Pancratov R, Rogatsky I, Neubert TA, Fisher EA, Garabedian MJ: Phosphorylation of liver $\mathrm{X}$ receptor alpha selectively regulates target gene expression in macrophages. Mol Cell Biol 28:2626-2636, 2008

21. Nomiyama $T$, Bruemmer D: Liver $X$ receptors as therapeutic targets in metabolism and atherosclerosis. Curr Atheroscler Rep 10:88-95, 2008

22. Makishima M, Okamoto AY, Repa JJ, Tu H, Learned RM, Luk A, Hull MV, Lustig KD, Mangelsdorf DJ, Shan B: Identification of a nuclear receptor for bile acids. Science 284:1362-1365, 1999

23. Ananthanarayanan M, Balasubramanian N, Makishima M, Mangelsdorf DJ, Suchy FJ: Human bile salt export pump promoter is transactivated by the farnesoid $\mathrm{X}$ receptor/bile acid receptor. J Biol Chem 276: 28857-28865, 2001

24. de Wit NJ, Bosch-Vermeulen H, de Groot PJ, Hooiveld GJ, Grootte Bromhaar MM, Jansen J, Muller M, van der Meer R: The role of the small intestine in the development of dietary fat-induced obesity and insulin resistance in $\mathrm{C} 57 \mathrm{BL} / 6 \mathrm{~J}$ mice. BMC Med Genomics 1:14, 2008

25. Watanabe M, Houten SM, Wang L, Moschetta A, Mangelsdorf DJ, Heyman RA, Moore DD, Auwerx J: Bile acids lower triglyceride levels via a pathway involving FXR, SHP, and SREBP-1c. J Clin Invest 113:1408-1418, 2004

26. Cynamon HA, Andres JM, Iafrate RP: Rifampin relieves pruritus in children with cholestatic liver disease. Gastroenterology 98:1013-1016, 1990 
27. Konno Y, Negishi M, Kodama S: The roles of nuclear receptors CAR and PXR in hepatic energy metabolism. Drug Metab Pharmacokinet 23:8-13, 2008

28. Lahtela JT, Arranto AJ, Sotaniemi EA: Enzyme inducers improve insulin sensitivity in non-insulin -dependent diabetic subjects. Diabetes 34:911-916, 1985

29. Kodama S, Koike C, Negishi M, Yamamoto Y: Nuclear receptors CAR and PXR cross talk with FOXO1 to regulate genes that encode drug-metabolizing and gluconeogenic enzymes. Mol Cell Biol 24:7931-7940, 2004

30. Zhang W, Patil S, Chauhan B, Guo S, Powell DR, Le J, Klotsas A, Matika R, Xiao X, Franks R, Heidenreich KA, Sajan MP, Farese RV, Stolz DB, Tso P, Koo SH, Montminy M, Unterman TG: FoxO1 regulates multiple metabolic pathways in the liver: effects on gluconeogenic, glycolytic, and lipogenic gene expression. J Biol Chem 281:10105-10117, 2006

31. Shin DJ, Osborne TF: PGC-1alpha activation of CYP7A1 during food restriction and diabetes is still inhibited by small heterodimer partner. J Biol Chem, 2008

32. Lee YS, Chanda D, Sim J, Park YY, Choi HS: Structure and function of the atypical orphan nuclear receptor small heterodimer partner. Int Rev Cytol 261: 117-158, 2007

33. Odom DT, Zizlsperger N, Gordon DB, Bell GW, Rinaldi NJ, Murray HL, Volkert TL, Schreiber J, Rolfe PA, Gifford DK, Fraenkel E, Bell GI, Young RA: Control of pancreas and liver gene expression by HNF transcription factors. Science 303:1378-1381, 2004

34. Ma K, Saha PK, Chan L, Moore DD: Farnesoid X receptor is essential for normal glucose homeostasis. J Clin Invest 116:1102-1109, 2006

35. Wang L, Huang J, Saha P, Kulkarni RN, Hu M, Kim Y, Park K, Chan L, Rajan AS, Lee I, Moore DD: Orphan receptor small heterodimer partner is an important mediator of glucose homeostasis. Mol Endocrinol 20:2671-2681, 2006 